\title{
Metric forestry: A measure of progress
}

\author{
ROBERT E. KEEN
}

Metric Conversion

Forest Management Institute

Department of the Environment

Ottawa, Ontario

Working Groups - 8.1.2 - Inventory and Mapping of Sector Committee 8.1 - Forestry,

Metric Commission

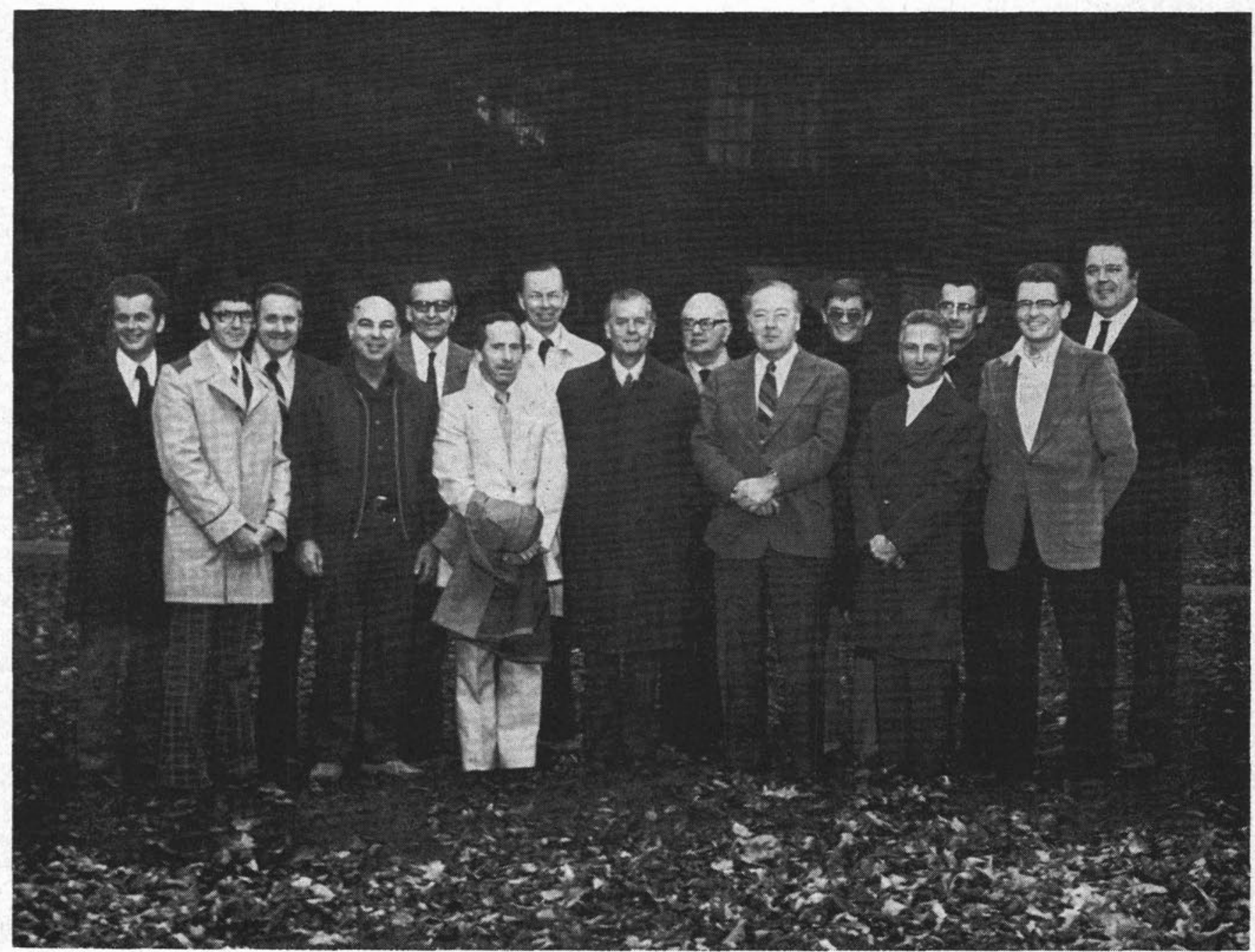

From Left to Right:

G. M. Bonnor F.M.I., Canadian Forestry Service;

Y. Richard

R. H. Lamont

D. Tackle*

M. R. Fajrajsl

P. H. Tremblay

B. M. Smith
Quebec Department of Lands and Forests:

Manitoba Mines, Resources and Environmental Management;

U.S. Forest Service;

Department of Indian and Northern Affairs;

Quebec Department of Lands and Forests:

New Brunswick Department of Natural Resources;
G. W. Allison

W. L. Plonski

A. Bickerstaff*

J. A. Benson

I. S. Alemdag*

H. W. F. Bunce

J. J. Lowe

R. E. Keen

*Observers
British Columbia Forest Service;

Ontario Ministry of Natural Resources:

Canadian Forestry Service;

Saskatchewan Department of Tourism and Renewable Resources;

F.M.I., Canadian Forestry Service;

Reid Collins and Associates Limited;

Alberta Department of Lands and Forests:

F.M.I., Canadian Forestry Service;

April 1975 The Forestry Chronicle 
METRIC FORESTRY

\section{A Measure of Progress}

The 1970 Government White Paper on Metric Conversion made three main points:

(a) that metric conversion in Canada is inevitable. Ninety percent of the world's population uses, or is committed to the use of metric measurement.

(b) the conversion process in Canada is voluntary.

(c) the system of metric measurement to be adopted by Canada will be the Système International d'Unités ( $\mathrm{SI})$. Metric measurement is simple, since it is the application of the decimal number system to measurements.

Based on a recommendation in the White Paper, the Metric Commission was established by Orderin-Council in June 1971, to prepare an overall plan for metric conversion. In turn, the Metric Commission established 11 Steering Committees, each responsible for coordinating a group of economic sectors with related interests. The Commission also established 60 Sector Committees that report to their respective Steering Committees. Each Sector Committee is responsible for a particular industry, group of industries or interests.

Throughout this article the words "committee" or "subcommittee" are admittedly very frequently used. However, the work of organizing for metric conversion in forestry, as in most other occupations and professions in Canada, is essentially that of committees - groups of persons voluntarily gathered together to investigate, consider, and report or take action on matters of common interest.

A total of 15 committee meetings have been held in the past year related to forestry metric conversion. These meetings have accomplished most of the "homework" necessary to undertake a planned, logical conversion to metric usage. Canada's forestry community should be very appreciative of the hard work being done by the committee members.

Steering Committee 8 is composed of five Sector Committees: 8.1 - Forestry, 8.2 - Wood Products, 8.3 - Furniture and Fixtures, 8.4 - Paper and Allied Industries, and 8.5 - Printing and Publishing. It is chaired by Commissioner G. Draeske of the British Columbia Council of Forest Industries.

\section{SECTOR COMMITTEE 8.1 - FORESTRY}

This committee is responsible for formulating the basic plans for converting the Forestry Sector to metric usage. In addition to planning the conversion of forestry measurement practices to the use of metric ( $\mathrm{SI})$ units, the program includes the identification of other areas within forestry that can be improved during the conversion process. For example, national roundwood scaling standards are being prepared in metric units and the same training program for metric will be used to train scalers in the use of these standards.

The entire Sector Committee 8.1 - Forestry met in December, 1973 for the first time. Membership included representatives of all the provinces, the

\section{Abstract}

The Canadian Metric Commission's committee organization and function are briefly described. The work of Sector Committees 8.1 - Forestry and 8.2 - Wood in particular, since their formation to date, is reported. Highlights of the four working groups of Sector Committee 8.1 - Forestry: Research, Inventory and Mapping, Scaling, and Planning are mentioned. Details are given of the first meeting of the Canadian Standards Association Committee on Scaling in Metric (SI) Units of Primary Forest Products. Recommendations of Sector Committee 8.2 - Wood are listed. Sector planning of conversion timing is discussed.

\section{Résumé}

L'organisation et la fonction du comité de la Commission du Système métrique sont décrites brièvement. Le travail des Comités sectoriels 8.1 - Foresterie et 8.2 - Bois particulièrement, depuis leur formation jusqu'à date, est relaté. Les points importants des quatre groupes de travail du Comité sectoriel 8.1 - Foresterie: Recherche, Inventaire et Cartographie, Mesurage, et Planification sont mentionnés. $Y$ sont donnés les détails de la première réunion du Comité de Mesurage en Unités métriques (SI) des Produits forestiers primaires, de I'Association canadienne de Normalisation. Apparaissent les recommandations du Comité sectoriel 8.2 - Bois. La planification des dates de conversion est aussi discutée.

Northwest and the Yukon Territories, the forest industry and its various associations, universities, and the Canadian Forestry Service (CFS) - a total of 30 members. Chairman of the Sector Committee is R. E. Keen of the CFS, with Co-Chairman R. B. Loughlan of the Ontario Forest Industries Association (OFIA). The structure of the Committee and its relationship within the Metric Commission are shown in the Chart.

The activities of the Sector Committee in planning and implementing metric conversion in Canadian forestry encompass all forest management practices and wood harvesting operations.

Early in 1974, the Forestry Sector Committee formed four working groups: 8.1.1 - Research, 8.1.2 - Inventory and Mapping, 8.1.3 - Scaling (roundwood), and 8.1.4 - Planning. The highlights of the activities of these working groups follow:

\subsection{1 - Research}

This working group is determining what metric units will be used in all forestry disciplines. It is recommended that all reseàrch publications should express quantities and ratios in metric units by January, 1975. Equivalent yard/pound units may be used with the metric units in publications if necessary, but they should be eliminated by 1978 . Most new research projects started in 1974 used metric units in basic measurements.

\subsection{2 - Forest Inventory and Mapping}

Metric units will be used in all field work in provincial forest inventories by 1976 . Saskatchewan has been using metric measurement in forest inventory for two years. Some of the recommendations made by this committee are:

Diameter Breast Height (DBH) be defined as 1.30 metres above ground level;

All volume calculations and reports on forest in- 


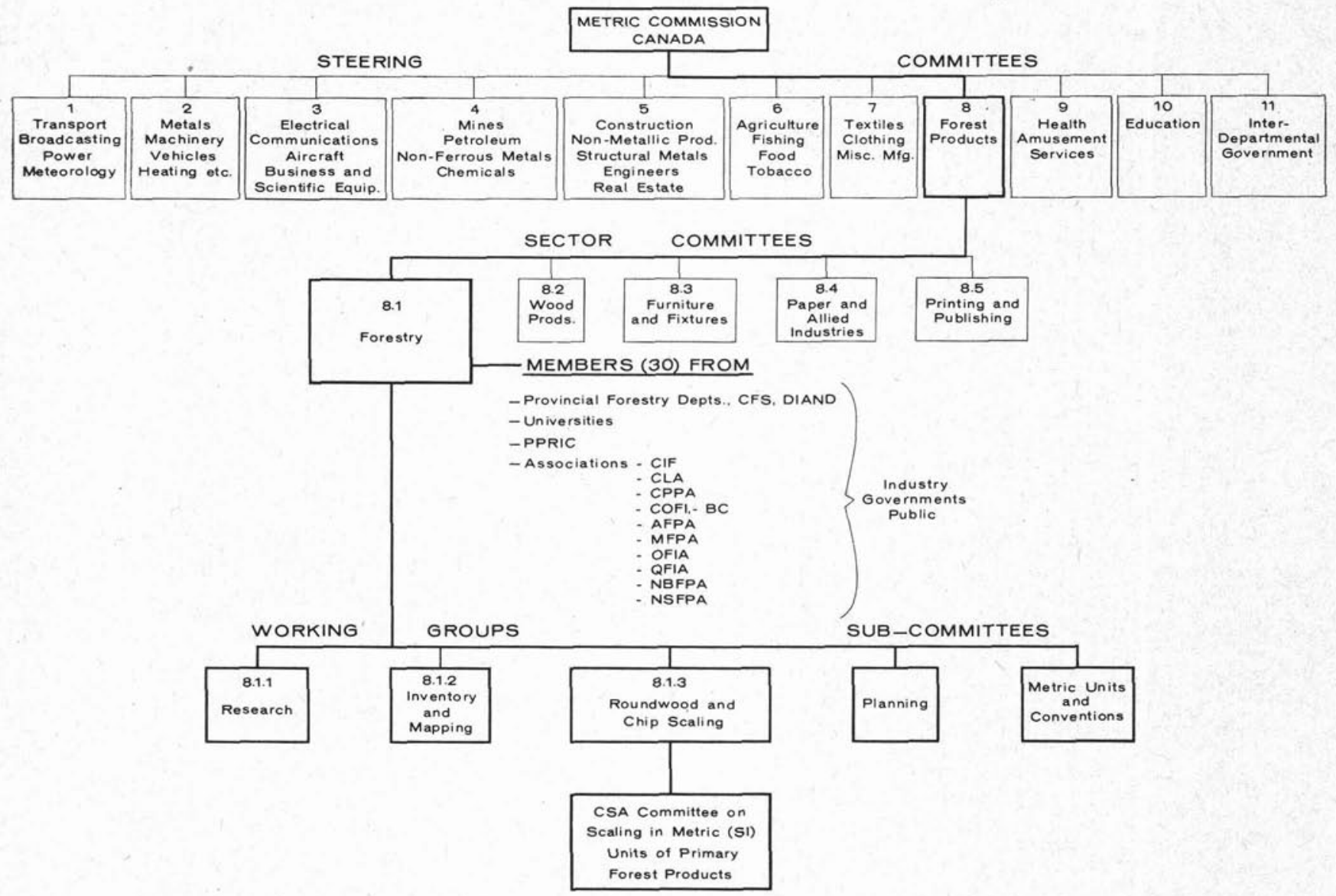

ventories be only in cubic metres $\left(\mathrm{m}^{3}\right)$;

Map ratios 1:12 500 and $1: 15000$ be included in the preferred 1, 2 and 5 series (i.e. 1:10 000, 1:20 000 and 1:50000). Contour intervals also will be in that series: 1, 2 or 5 metres.

\subsection{3 - Scaling (roundwood)}

The first meeting of the Canadian Standards Association (CSA) Committee on Scaling in Metric (SI) Units of Primary Forest Products was held November 21-22, 1974, at Montebello, P.Q. Twentyeight members, representing provincial and federal governments, the forest industry and forestry faculties were present; also in attendance was an observer from the Forest Service of the United States Department of Agriculture. Chariman of the Committee is T. G. Honer of the CFS Pacific Forest Research Centre, Victoria, B.C. A secretariat for this Committee is being provided by CFS - Forest Management Institute, namely M. G. Bowen and W. G. Harris.

The Committee, formed to develop National Scaling Standards for the measurement of primary forest products in Canada, evolved from the Metric Commission's Sector Committee 8.1 - Forestry, Working Group 8.1.3 - Scaling. The Working Group had met four times since February, 1974, and at its final meeting in Victoria, B.C., in September, recommended that a Canadian Standards Association Committee be formed to meet the urgent need for standardization of wood measurement practices in Canada.
The Montebello meeting concerned itself first with the Committee's terms of reference. It was agreed that, as well as preparing the scaling Standards, the work of the Committee would include monitoring developments in scaling methods in North America and elsewhere, recommending necessary research and in the long term, keeping the Standards up to date. A list of definitions used in wood measurement was presented and discussed. Then R. F. DeGrace of the Canadian Wood Council and Chairman of CSA Sectional Committee 0 Timber, gave a brief talk on the criteria and procedures for writing National Standards in Canada.

Ten background papers prepared by Working Group 8.1.3 - Scaling were reviewed by the Committee. It was decided that three of these reports would be written into draft standards before the next meeting of the Committee. These covered cubic scale of individual pieces, piece and linear measures, and chip measurement.

Nine subcommittees were formed, each consisting of from two to five members. Each subcommittee was asked to prepare Standards on a particular type of product measurement, softwood and hardwood, such as logs, tree lengths, weigh scaling, chips, and stacked wood.

The timetable for metric conversion of the forest industry, which has a tentative completion date of 1979 , sets the timing of the preparation of this Standard. The Committee is to prepare a National Standard and have it approved by the provincial agencies, so that both scaling training manuals and 
legislation changes can be prepared. This will be followed by a retraining program for scalers on a schedule that will permit the date for metric conversion to coincide with the planned conversion date of the forest industry.

The Committee unanimously recommended that the use of "board feet" or "board measure" for roundwood scaling be discontinued. The date of the next meeting of the CSA Scaling Committee was set tentatively for May, 1975.

\subsection{4 - Planning}

The Sector Plan is to be presented to the Steering Committee of the Metric Commission in March, 1975. When the Sector plan has been melded with those of other Sectors early in 1975, the timing of training and implementation will be announced by members of Sector Committee 8.1 - Forestry. The Sector Committee members will implement the program through provincial and federal agencies, forestry associations, industry organizations and educational institutions to reach every Canadian concerned with forestry.

\section{Subcommittee on Metric Units and Conventions}

The Working Groups 8.1.1, 8.1.2, and 8.1.3 each recommended a set of specific metric units for forestry in Canada. This subcommittee collated these decisions and prepared for Sector Committee 8.1 its first publication, "Selected Metric (SI) Units and Conversion Factors for Canadian Forestry", which has already been widely distributed. The publication was issued as early as possible to provide basic information to forestry students. When the 1974 freshman class graduates, metric conversion in forestry will have been implemented.

The Sector Committee, with additional input from the Technical Working Groups, is preparing a publication "Metric Forestry". It is intended to serve as a supplementary metric practice guide for forestry and will contain a listing of metric conversion factors and standards. It will also contain metric volume tables and tables of general forestry use. Conversion tables will not be included, since they encourage non-metric thinking. This publication should be available for training purposes early in 1976 .

\section{Canadian Council on Forest Fire Control - Subcommittee on Metric Conversion}

Although not a committee of the Metric Com- mission, this Subcommittee, chaired by W. L. Sleeman, Ministry of Natural Resources, Ontario, has been working within the Commission's timing guidelines. The Subcommittee has examined forest fire equipment sizes and recommended certain metric sizes. Their main approach is the development of a standard size, quick-disconnect hose coupling that will be acceptable to all forest fire control agencies. Several equipment suppliers have shown interest in developing a coupling with the assistance of the Department of Industry, Trade and Commerce. A development agreement is expected within the next few months.

\section{SECTOR COMMITTEE 8.2 - WOOD (Products)}

Anyone concerned with forestry will also be interested in the activities of Sector Committee 8.2 Wood (Products), chaired by Mr. P. Desjardins, of Weldwood, and co-chaired by Mr. R. F. DeGrace of the Canadian Wood Council. This committee is composed of forest industry association members.

The areas covered by Sector 8.2 are best described by the subcommittees that have been formed. There are nine subcommittees in all. They are: 8.2.1 - Softwood Lumber, 8.2.2 - Hardwood Lumber; 8.2.3 - Panel Products; 8.2.4 - Sash Doors and Millwork; 8.2.5 - Laminating; 8.2.6 - Pallets and Miscellaneous; 8.2.7 - Preservation; 8.2.8 - Poles and Piling; and 8.2.9 - Shingles.

Sector Committee 8.2 has made these basic recommendations:

1. Lumber products to be marketed on the basis of actual finished dry sizes;

2. Board measure (fbm) be discontinued as a unit of lumber volume;

3. The preferred size of panels be $1200 \mathrm{~mm} \mathrm{x}$ $2400 \mathrm{~mm}$;

4. The conversion timing be closely coordinated with that of the USA, which provides 60 percent of the Canadian lumber market;

5. Although each product subcommittee is responsible for defining conversion timing, the Sector Committee will prepare a coordinated schedule to convert all wood products at the same time. A tentative timetable drawn up by the Planning Subcommittee of Sector 8.2 proposes conversion of wood products early in 1979. Prior to this, product sizes must be agreed upon, standards changed, personnel trained, and equipment modified, so that products in metric measurement may be marketed at that time.

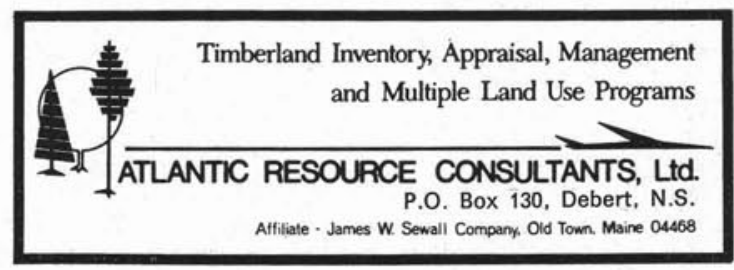

